\title{
Environmental distribution and diversity of insecticidal proteins of Bacillus thuringiensis Berliner
}

\author{
Xavier, R., ${ }^{*}$ Reena Josephine, C.M. and Sreeramanan, S. \\ Department of Biotechnology, Faculty of Applied Sciences, AIMST University, Semeling, 08100 Bedong, Kedah Darul \\ Aman, Malaysia. \\ E-mail: rxavier77@hotmail.com
}

\begin{abstract}
Bacillus thuringiensis Berliner based biopesticides have been successfully used world over for the control of agricultural pests and vectors of human diseases. Currently there are more than $200 \mathrm{~B}$. thuringiensis strains with differing insecticidal activities are available as biocontrol agents and for developing transgenic plants. However, two major disadvantages are the development of insect resistance and high target specificity (narrow host range). Globally there is a continuous search for new $B$. thuringiensis strains with novel insecticidal activities. The present study aims to study the environmental distribution of $B$. thuringiensis and their toxic potential against insect pests. Soil and grain samples were collected from different environments and were processed by a modified acetate selection method. Initially $B$. thuringiensis isolates were screened on the basis of colony morphology and phase contrast microscopy for the presence of parasporal crystal inclusions. The population dynamics showed that $B$. thuringiensis is abundant in sericulture environment compared to other niches. Relative abundance of $B$. thuringiensis strains in sericulture environment shows the persistent association of $B$. thuringiensis with Bombyx mori (silk worm) as insect pathogen. The protein profiles of the selected strains were studied by SDS-PAGE. The protein profiles of majority of $B$. thuringiensis isolates from grain storage facilities predominantly showing the $130 \mathrm{kDa}$ and $68 \mathrm{kDa}$ proteins, which is characteristics of lepidopteran active $B$. thuringiensis. However, one isolate BTRX-4 has $80-85 \mathrm{kDa}$ protein, which is novel in that, this strain also exhibits antilepidopteran activity, which is normally presented by $B$. thuringiensis strains having $130 \mathrm{kDa}$ and $68 \mathrm{kDa}$ proteins. The protein profile of $B$. thuringiensis isolates from sericulture environment shows two different protein profiles. $B$. thuringiensis isolates BTRX-16 to BTRX-22 predominantly show $130 \mathrm{kDa}$ protein, however, the $B$. thuringiensis isolates BTRX-23 to BTRX-30 have two distinct protein profiles corresponding to $130 \mathrm{kDa}$ and $68 \mathrm{kDa}$. These results show that there may be more than one $B$. thuringiensis strain that can infect Bombyx mori. The preliminary bioassay against second instar larvae of Heliothis armigera showed varying mortality rate. In conclusion, despite the ubiquitous presence of $B$. thuringiensis strains in different environments, specifically the sericulture environment supports $B$. thuringiensis in a significant manner compared to other environments. Further the ICPs produced by different strains of $B$. thuringiensis are unique in terms of the protein profile and hence may also differ in their insecticidal activities.
\end{abstract}

Keywords: Bacillus thuringiensis, biopesticides, insecticidal crystal proteins

\section{INTRODUCTION}

Synthetic insecticides have long been regarded as a panacea for the control of pests and diseases in crop plants. However, their use is limited because of environmental concerns and health problems in human beings (Zimmermann et al., 2005). Bacillus thuringiensis Berliner is a gram positive soil bacterium that has been successfully used as a biocontrol agent for more than fifty years (Navon, 2000). The insecticidal crystal proteins (ICP) produced by $B$. thuringiensis are highly specific, safe to non-target organisms including humans, completely degradable and eco-friendly (Schnepf et al., 1998). These toxins have highly specific activity against the larval forms of the insects belonging to the insect orders Lepidoptera, Diptera, and Coleoptera (Feitelson et al., 1992). The horizon of insecticidal activity of $B$. thuringiensis is ever expanding, as new strains of $B$. thuringiensis have been demonstrated to be active against a wide range of insects including cockroaches (Blatta orientalis) (Porcar et al.,
2006). The insecticidal crystal proteins are encoded by the cry genes normally present in the plasmids. To date, over 200 cry gene sequences have been determined and classified into 44 families and different subclasses (Crickmore et al., 2005). The mode of action of the Cry proteins involves solubilization of the crystal protein, processing of the protoxins by intestinal proteases, and recognition of a binding site on the midgut brush border membrane surface, followed by pore formation and cell lysis, leading ultimately to insect death (Vachon et al., 2002). Recent information suggests that the vegetative insecticidal proteins (Vip) are also toxic to insects. Vip proteins are secreted during vegetative growth and do not exhibit any similarity to Cry or Cyt toxins. Currently, all Vip-related sequences that have been described fall into three different families, Vip1, Vip2, and Vip3 (Crickmore et al., 2005). The Vip1 and Vip2 proteins are the two components of a binary toxin that exhibit toxicity to coleopterans (Han et al., 1999). Vip3 proteins have a different host range, which includes several major

\section{*Corresponding author}


lepidopteran pests (Bhalla et al., 2005). Owing to the difference in the mode of action compared with Cry toxins, Vip proteins are good candidates for resistance management strategies involving stacking or rotation of proteins with different insecticidal mechanisms (Rang et al., 2005).

Intensive screening programs all over the world, have identified $B$. thuringiensis strains from soil samples, plant surfaces, dead insects, and stored grains. The search for new $B$. thuringiensis strains is a continuous process, since a significant number of pests are not controlled with the available Cry proteins. It is also important to provide alternative means of coping with the problem of insect resistance, especially with regard to the expression of $B$. thuringiensis genes encoding insecticidal proteins in transgenic plants (Van Rie, 1991). The present study aims to isolate native $B$. thuringiensis strains from different environments, to understand their environmental distribution, insecticidal potential in relation to the protein profile.

\section{MATERIALS AND METHODS}

\section{Sample collection}

Soil samples were collected primarily from diverse environments, including the agricultural fields in a sericulture (silkworm) environment. Samples were collected by scraping off surface material with a sterile spatula and then collecting a $5 \mathrm{~g}$ sample, $2 \mathrm{~cm}$ below the surface. These samples were stored in sterile plastic bags at ambient temperature. Samples were also collected from poultry feed mills and warehouses, where cereals and pulses were stored. Approximately $2 \mathrm{~g}$ of sample was collected by scooping the materials into sterile plastic vials. The samples included broken grain dust, dead insects, insect webbings and rodent excreta.

\section{Isolation of $B$. thuringiensis}

A modified acetate selection method was used to isolate B. thuringiensis from the samples (Travers et al., 1987). Five gram of the sample was added to $10 \mathrm{ml}$ of Luria Bertani (LB) broth containing $0.25 \mathrm{M}$ sodium acetate in $100 \mathrm{ml}$ flask. Sodium acetate selectively inhibits the germination of $B$. thuringiensis spores. The broth was inoculated on a shaker $(200 \mathrm{rpm})$ for $4 \mathrm{~h}$ at $30^{\circ} \mathrm{C}$. The broth was thoroughly mixed and then $1 \mathrm{ml}$ aliquot was heated at $80^{\circ} \mathrm{C}$ for $10 \mathrm{~min}$ (Akiba and Katoh, 1986) in a pre-warmed $6 \mathrm{ml}$ glass test tube and serially diluted aliquots were plated on LB agar and incubated overnight at $30^{\circ} \mathrm{C}$. Based on $B$. thuringiensis colony morphology and phase contrast microscopy colonies were selected at random.

\section{Polymerase chain reaction (PCR)}

Total DNA extracted from suspected $B$. thuringiensis isolates were used in PCR to identify the $B$. thuringiensis strains harbouring cry genes using the primer Lep1A and
Lep2B (Carozzi et al., 1991). A Perkin- Elmer Gene Amp PCR system 9600 thermal cycler was used for DNA amplification. Ten $\mu \mathrm{L}$ of crude lysate was added to $90 \mu \mathrm{L}$ of PCR mix, containing 1X PCR buffer, $2 \mathrm{mM}$ deoxy nucleotide triphosphates, primers, double distilled water and $2.5 \mathrm{U}$ Taq polymerase. The contents were mixed by gentle pipetting and overlaid with $30 \mu \mathrm{l}$ of mineral oil. The step cycle program in the thermal cycler was set to denature at $95{ }^{\circ} \mathrm{C}$ for $1 \mathrm{~min}$, anneals at $48{ }^{\circ} \mathrm{C}$ for $1 \mathrm{~min}$ and extended at $72{ }^{\circ} \mathrm{C}$ for $3 \mathrm{~min}$ for a total of 35 cycles. Following amplification, the PCR products were electrophorsed on $0.7 \%$ agarose gel with ethidium bromide (Sambrook et al., 1989).

Lepidopteran specific PCR Primers:

Lep1A: 5' CCGGTGCTGGATTTGTGTTA3'

Lep2B: 5' TACATGCCCTTTCACGTTCC3'

\section{Protein estimation and SDS-PAGE}

The protein estimation was carried out as per the protocol of Lowry et al. (1951). Proteins present in cell extracts were analyzed by SDS-PAGE according to the Laemmli method (1970). Electrophoresis was performed at room temperature at a constant current of $30 \mathrm{~mA}$. On completion, the gel was stained with Coomassie Brilliant Blue and the excess stained was removed with destaining solution.

\section{Bioassay}

The isolates were cultured at $30{ }^{\circ} \mathrm{C}$ in $250 \mathrm{ml}$ flasks in KTB medium (K-mineral salts medium $15 \mathrm{~g}\left(\mathrm{NH}_{4}\right)_{2} \mathrm{SO}_{4}$, $0.2 \mathrm{~g} \mathrm{MgSO}{ }_{4} .7 \mathrm{H}_{2} \mathrm{O}, 0.403 \mathrm{~g} \mathrm{KH}_{2} \mathrm{PO}_{4}, 2.96 \mathrm{~g} \mathrm{~K}_{2} \mathrm{HPO}_{4}$, distilled water $1000 \mathrm{ml}$ supplemented with $25 \%$ tryptose broth and the final $\mathrm{pH}$ was 7.5) (Meenakshi and Jayaraman, 1979) at $250 \mathrm{rpm}$. During growth the cultures were periodically examined for sporulation. Cultures were harvested when at least $95 \%$ of the population had lysed releasing spores and crystals as determined by microscopic examination. To remove the exotoxin, the broths were centrifuged and pellets were resuspended in distilled water. This spore crystal mixture was used for bioassay. Preliminary studies on the larvicidal activity of $B$. thuringiensis isolates were tested against the second instar larvae of Heliothis armigera at a fixed dose of 300 $\mu \mathrm{g} / \mathrm{ml}$ of spore crystal mixture, using surface contamination method (Beegle, 1989). The spore crystal suspension in sterile distilled water containing $0.02 \%$ Triton X-100 was smeared on the natural diet (Bhendi vegetable) and air dried at room temperature. The larvae were fed on the contaminated food at $25{ }^{\circ} \mathrm{C}$ and the mortality was recorded after $72 \mathrm{~h}$.

\section{RESULTS AND DISCUSSION}

\section{Population dynamics}

$B$. thuringiensis has been found to occur naturally in diverse habitats. $B$. thuringiensis spores have been 
recovered from nearly every kind of soil (Martin and Travers, 1989). Strains of $B$. thuringiensis have also been isolated from grain dust (Meadows, 1992) in sericulture environment (Ohba and Aizawa, 1986). The samples collected in this study were categorized into three major groups based on their source, such as grain storage facilities including animal feed mills, soil samples from sericulture based agricultural regions and soil samples from non-sericulture regions. It is evident that, among the three groups of samples subjected for screening those collected from the sericulture region were enriched with $B$. thuringiensis isolates compared to those collected from other environments (Table 1). Adverse environmental and climatic factors and the problem of adherence to soil particles may be the reasons for the lack of $B$. thuringiensis spores in soils from non-sericulture environment as observed by De Luca et al (1981). However, the high frequency of recovery of $B$. thuringiensis in sericulture environment shows that the persistent association of this insect pathogen with Bombyx mori, over a period of time. The results of this study showed that $B$. thuringiensis can be recovered from grain dust and soil samples, especially from sericulture-based agricultural regions.

Table 1: Population dynamics of $B$. thuringiensis isolates obtained from different environmental sources

\begin{tabular}{|c|c|c|c|c|c|}
\hline & $\begin{array}{c}\text { Total } \\
\text { number of } \\
\text { samples }\end{array}$ & $\begin{array}{l}\text { Number of } \\
\text { spore } \\
\text { forming } \\
\text { isolates }\end{array}$ & $\begin{array}{c}\text { Number of isolates } \\
\text { resembling } B . \\
\text { thuringiensis } \\
\text { morphology (ICP) }\end{array}$ & $\begin{array}{l}\text { Number of } \\
\text { PCR positive } \\
\text { isolates for } \\
\text { cryl primers }\end{array}$ & $\begin{array}{c}\text { Percentage } B . \\
\text { thuringiensis } \\
\text { strains in the } \\
\text { population }\end{array}$ \\
\hline Grain storage facilities & 100 & 62 & 28 & 15 & 15 \\
\hline $\begin{array}{l}\text { Soil from sericulture } \\
\text { environment }\end{array}$ & 50 & 40 & 32 & 15 & 30 \\
\hline $\begin{array}{l}\text { Soil from non- } \\
\text { sericulture } \\
\text { environment }\end{array}$ & 50 & 21 & nil & nil & nil \\
\hline
\end{tabular}

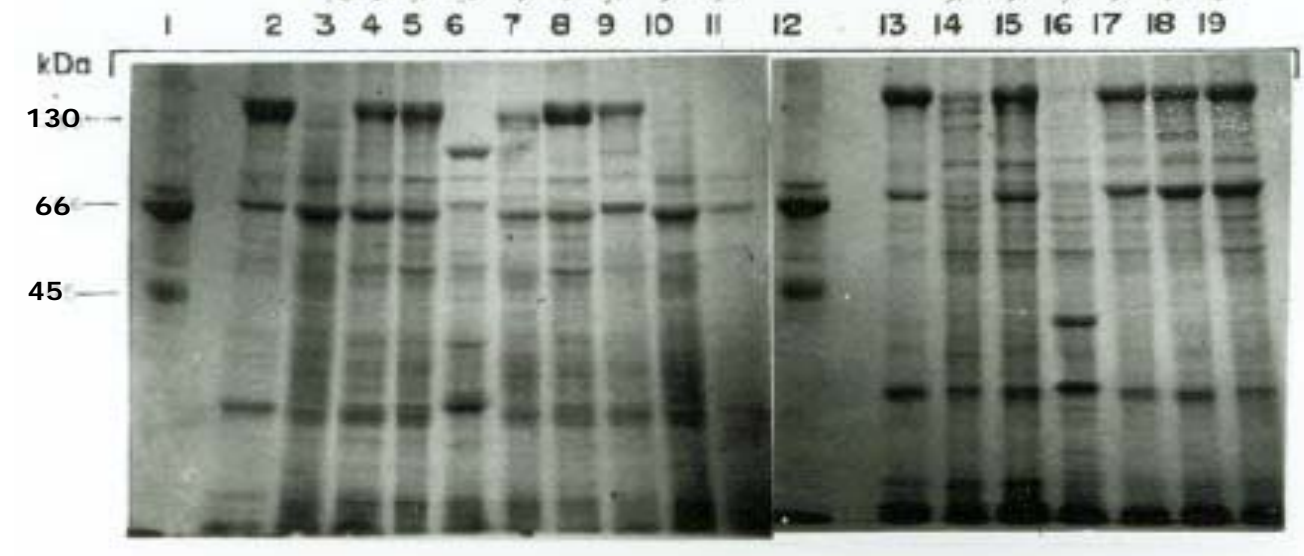

Figure 1. SDS-PAGE analysis of isolates of $B$. thuringiensis strains from stored grain samples

Lane 1. Molecular weight standard

Lane 2. B. thuringiensis subsp. galleriae

Lane $3-11$. B. thuringiensis isolates from stored grain samples

Lane 12. Molecular weight standard

Lane 13. B. thuringiensis subsp. galleriae

Lane 14-19. B. thuringiensis isolates from stored grain samples 


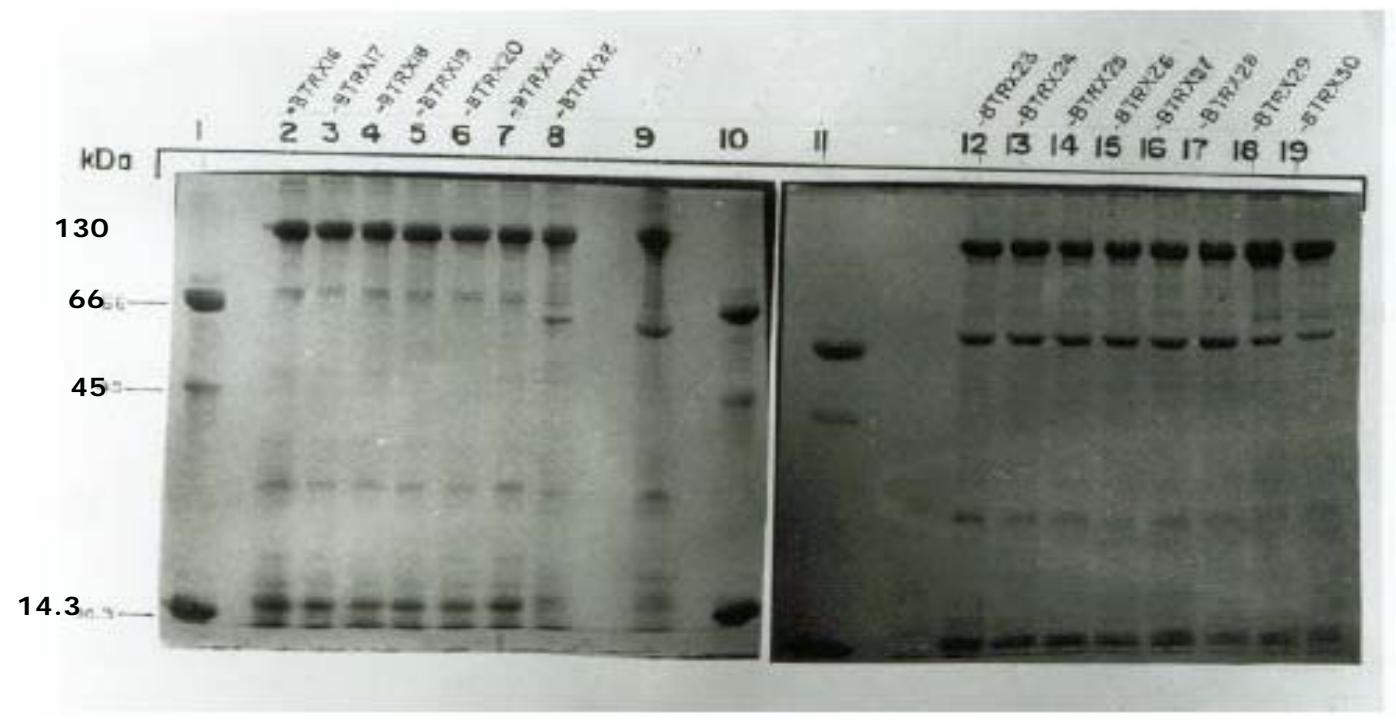

Figure 2. SDS-PAGE analysis of $B$. thuringiensis isolates from soil samples from sericulture environment Lane 1. Molecular weight standard

Lane 2-8. B. thuringiensis isolates from soil samples from sericulture environment

Lane $9 \& 13$. B. thuringiensis subsp. galleriae

Lane 10-11. Molecular weight standard

Lane 12-19. B. thuringiensis isolates from soil samples from sericulture environment

The results showed that most of $B$. thuringiensis isolates produced a protein profile similar to that of Lepidopteran - specific $B$. thuringiensis strains with 130 $\mathrm{kDa}$ and $68 \mathrm{kDa}$ proteins. However, a few isolates showed varying protein pattern. Particularly, isolate BTRX-4 from grain samples (Fig 1, lane 6) showed a characteristic protein profile with the protein of approximately $80-85 \mathrm{kDa}$. In contrast, the protein profile of all the $B$. thuringiensis isolates from sericulture environment showed a typical Lepidopteran pattern having approximately $130 \mathrm{kDa}$ and $68 \mathrm{kDa}$ proteins (Fig 2 ). A deeper insight into these protein profiles of $B$. thuringiensis isolates from sericulture environment reveals that isolates BTRX-16 to BTRX-22 (Fig 2, Lanes 2 to 8 ), the expression of the $68 \mathrm{kDa}$ protein is comparatively lesser to that of the isolates BTRX-23 to
BTRX-30 (Fig 2, Lanes 12 to 19). This differential expression indicates that there may be more than one $B$. thuringiensis strain in that particular environment. Further, B. thuringiensis strains isolated from grain samples also exhibited a high diversity in terms of protein profile (Fig 1). The possible reason for this may be the emergence of diverse populations of $B$. thuringiensis brought about by a natural process of plasmid transfer in stored product environment (Meadows et al., 1992).

\section{Bioassay}

The results showed that all the thirty $B$. thuringiensis isolates were toxic to the second instar larvae of Heliothis armigera and the mortality ranged from $40 \%$ to $100 \%$ (Table 2).

Table 2: Larvicidal activity of $B$. thuringiensis isolates against second instar larvae of Heliothis armigera

\begin{tabular}{cc}
\hline B. thuringiensis isolates & $\begin{array}{c}\text { \% Mortality* } \\
\text { (Mean of three replications) }\end{array}$ \\
\hline BTRX1 10 \\
BTRX 2,4,5,6,8,9,10,12 & 60 \\
BTRX 3,7,11,13,14,15,16,19,20,21,22,25,26,29,30 & 80 \\
BTRX17,18,23,27 & 90 \\
BTRX 24,28 & 100 \\
\hline
\end{tabular}

${ }^{*}$ After 72 hours of exposure. 
The objective of this preliminary bioassay is to understand the insecticidal potential of the diverse ICP in nature and to identify the entomocidally potent $B$. thuringiensis isolates. It is interesting to note that the majority of the $B$. thuringiensis isolates that are exhibiting higher mortality had the $130 \mathrm{kDa}$ protein, which is characteristic of antilepidopteran $B$. thuringiensis strains (Yamamoto and Powell, 1993). The less active ones especially BTRX 1,4,8,9,10 and 12 are expressing proteins other than $130 \mathrm{kDa}$ proteins. However, insecticidal activity of these may be attributed to other confounding factors such as the proteases, phospholipases, chitinases. The $B$. thuringiensis isolates with elevated level of insecticidal activity are from the sericulture environment. As these isolates are naturally toxic to Bombyx mori, a member of the insect order Lepidoptera, they could also be toxic to other lepidopteran larvae, however with differing toxicity. The $B$. thuringiensis isolates from soils from non sericulture environment and grain storage facilities were relatively less toxic to Heliothis armigera, as these environments are less preferred by lepidopteran larvae. From this study it may be hypothesized that the environmental distribution and the insecticidal specificity of $B$. thuringiensis strains are primarily based on the prevalence and abundance of the target insects in a particular environment and the cry gene content of the $B$. thuringiensis strains.

\section{CONCLUSIONS}

Though $B$. thuringiensis is a soil bacterium, it has been isolated from different environments. As the environment is diverse, hence the insecticidal proteins are also diverse showing differential insecticidal activities. The present study demonstrated how the $B$. thuringiensis isolates from diverse habitats differ in their protein profile, which is reflected in varying levels of insecticidal activity. Continuous efforts to isolate novel $B$. thuringiensis strains from different environments and genetic manipulation of such strains may be helpful in solving the problems such as insect resistance and narrow host range.

\section{REFERENCES}

Akiba, Y. and Katoh, K. (1986). Microbial Ecology of Bacillus thuringiensis $\mathrm{V}$. Selective medium for Bacillus thuringiensis vegetative cells. Applied Entomology and Zoology 21: 210 - 215.

Beegle, C.C. (1989). Bioassay methods for quantification of Bacillus thuringiensis delta-endotoxin. In: Hickle, L.A. and Fitch, W.L.(eds), Analytical Chemistry of Bacillus thuringiensis ACS Symposium Series 432.

Bhalla, R., Dalal, M., Panguluri, S.K., Jagadish, B., Mandaokar, A.D., Singh, A.K. and Kumar, P.A. (2005). Isolation, characterization and expression of a novel vegetative insecticidal protein gene of Bacillus thuringiensis FEMS Microbiological Letters, 243: 467 - 472.
Carozzi, N.B., Kramer, V.C., Warren, G.W., Evola, S. and Koziel, M.G. (1991). Prediction of insecticidal activity of Bacillus thuringiensis starins by polymerase chain reaction product profiles. Applied and Environmental Microbiology, 57: 3057 - 3061.

Crickmore, N., Zeigler, D.R., Schnepf, E., Van Rie, J., Lereclus, D., Baum, J., Bravo, A. and Dean, D.H. (2005). Bacillus thuringiensis toxin nomenclature. [Online.] http://www.biols.susx.ac.uk/Home/Neil Crickmore/Bt index.html.

De Lucca, A.J., Simonson, J.G. and Larson, A.D. (1981). Bacillus thuringiensis distribution in soils of the United States. Canadian Journal of Microbiology 27: $865-870$.

Feitelson, J.S., Payne, J. and Kim, L. (1992). Bacillus thuringiensis: insects and beyond. Biotechnology 10: $271-275$.

Han, S., Craig, J.A., Putnam, C.D., Carozzi, N.B. and Tainer, J.A. (1999). Evolution and mechanism from structures of an ADP-ribosylating toxin and NAD complex. Natural Structural Biology 6: 932 - 936.

Laemmli, U.K. (1970). Cleavage of structural proteins during the assembly of the head of bacteriophage T4. Nature 227: $680-685$.

Lowry, O.H., Rosebrough, N.J., Farr, A.L. and Randall, R.J. (1951). Protein measurement with the folin phenol reagent. Journal of Biological Chemistry 193: 265 - 275.

Martin, P.A.W. and Travers, R.S. (1989). Worldwide abundance and distribution of Bacillus thuringiensis isolates. Applied and Environmental Microbiology 55: $2437-2442$.

Meadows, M.P., Ellis, D.J., Butt, J., Jarrett, P. and Burges, H.D. (1992). Distribution, frequency and diversity of Bacillus thuringiensis in an animal feed mill. Applied and Environmental Microbiology 58: $1344-1350$.

Navon, A. (2000). Bacillus thuringiensis insecticides in crop protection-reality and prospects. Crop Protection 19(8-10): 669 - 676.

Meenakshi, K. and Jayaraman, K. (1979). On the formation of crystal proteins during sporulation in Bacillus thuringiensis var. thuringiensis. Archives of Microbiology 120: 9 - 14.

Ohba, M. and Aizawa, K. (1986). Distribution of Bacillus thuringiensis from soils of Japan. Journal of Invertebrate Patholology 47: 277 - 282.

Porcar, M., Navarro, L. and Jimenez-Peydro, R. (2006). Pathogenicity of intra-thoracically administered Bacillus thuringiensis spores in Blatta orientalis. Journal of Invertebrate Pathology 93 (1): $63-66$.

Rang, C., Gil, P., Neisner, N., Van Rie, J. and Frutos, R. (2005). Novel Vip3-Relared Protein from Bacillus thuringiensis, Applied and Environmental Microbiology 71(10): 6276 - 6281.

Sambrook, J., Fritsch, E.F. and Maniatis, T.M. (1989). Molecular cloning: a Laboratory Manual, $2^{\text {nd }}$ edition, 
Cold Spring Harbor Laboratory press, Cold Spring Harbor, New York.

Schnepf, E., Crickmore, N., Van Rie, J., Lereclus, D., Baum, J., Feitelson, D., Zeigler, R. and Dean, D.H. (1998). Bacillus thuringiensis and its pesticidal crystal proteins. Microbiology and Molecular Biology Reviews 62: 775 - 806.

Travers, R.S., Martin, P.A. and Reichelderfer, C.F. (1987). Selective process for efficient isolation of soil Bacillus species. Applied and Environmental Microbiology 53: 1263 - 1266.

Vachon, V., Préfontaine, G., Coux, F., Rang, C., Marceau, L., Masson, R., Brousseau, R., Frutos, J. L., Schwartz and Laprade, R. (2002). Role of helix three in pore formation by the Bacillus thuringiensis insecticidal toxin Cry1Aa. Biochemistry 41:6178 - 6184.

Van Rie, J. (1991). Insect control with transgenic plants: resistance proof? Trends in Biotechnology 9: 177179.

Xavier, R. (1997). Ph.D theisis "Molecular Approaches To Identify Potent, Indigenous Isolates of Bacillus thuringiensis". Submitted to Anna University, Tamil Nadu, India.

Yamamoto, T. and Powell, G. (1993). Bacillus thuringiensis crystal proteins: recent advances in under standing its insecticidal activity. In: Kim, L. (ed), Advanced Engineered Pesticides. Marcel Dekker, Inc. New York, pp.3-42.

Zimmermann, E., Pedersen, J.O., Saraubon, K., Tjell, J.C. and Prapamontol, T. (2005). DDT in human milk from Chiang Mai mothers: a public health perspective on infants' exposure. Bulletin of Environmental Contamination and Toxicology 74(2): 407 - 414. 